\title{
ĐÁNH GIÁ CÁC TỔN THƯƠNG NHÚ VÀ MộT SỐ ĐẶC ĐIỂM LÂM SÀNG - GIẢI PHẪU BÊ̂NH CỦA VÚ
}

\section{TÓM TẮT}

Tổn thương nhú chỉ chiếm $2 \%$ các tổn thương của tuyến vú nhưng tổn thương này lại có nhiều đăc điểm có thể gây nhẩm lẫn giữa lành tính, không điển hình và ác tính trong cả chẩn đoán, phân loai và điều tri. Mục tiêu: Nhận xét một số đặc điểm lầm sàng, mô bệnh học và hóa mô miễn dịch của các tổn thương nhú ở tuyến vú. Đối tượng và phương pháp nghiên cứu: 79 bênh nhân tổn thương nhú được phân loại mô bệnh học và ghi nhận một số đặc điểm lâm sàng, $\mathrm{MBH}$, nhuộm HMMD với Ki67. Kết quả nghiên cứu: $100 \%$ típ UNNO có chỉ số Ki-67 thấp. Nhóm tốn thương nhú không điển hình có 1 trường hợp ghi nhận có chỉ số Ki-67 cao $(p<0,05)$. Trong nhóm tổn thương nhú ác tính có 5 trường hợp có chỉ số Ki-67 cao chủ yếu gặp ở típ UTBM nhú trong vỏ ( $p$ $>0,05)$. Kết luận: Tốn thương $A D H$ và $D C I S$ găp nhiêuu trong nhóm UTBM có câu trúc nhú hơn so với UNNO và khả năng phát triển thành UTBM có cấu trúc nhú ở nhóm có ADH cao gấp 6,5 lần so với nhóm không có ADH.

Tư khóa: Tổn thương nhú của vú, Đặc điểm lâm sàng - giải phẫu bệnh, Hóa mô miễn dịch.

\section{SUMMARY \\ ASSESSMENT OF THE BREAST PAPILLARY LESSIONS AND SOME \\ CLINICOPATHOLOGICAL FEATURES}

Papillary lesions only account for $2 \%$ of the mammary lesions, but this lesion ownes many features that can confuse between benign, atypical and malignant characteristic in the diagnosis, classification and treatment. Purpose: Comment on some clinical features, histopathology and immunohistochemistry of papillary lesions in breast. Methods: 79 patients with papillary lesion were classified in histopathological subgroups by WHO classification, reviewing some clinicopathological characteristics, IHC stain of Ki67 marker. Results: $100 \%$ intraductal papilloma has a low Ki67. Atypical papillary lesion group was seen in 1 case with a high Ki67 score $(p<0.05)$. In the group of malignant papillary lesions, there were 5 cases with high Ki67, mainly seen in type of encapsulated papillary carcinoma ( $p<0,05)$. Conclusion: ADH and DCIS were more common in the group of papillary carcinoma than intraductal papilloma, and the likelihood of developing papillary carcinoma of the $\mathrm{ADH}$ group was 6.5 times higher than in the lession

\section{*Bênh viên $K$}

Chịu trách nhiệm chính: Nguyễn Tiến Quang

Email: ntienquangbvk@gmail.com

Ngày nhận bài: 2.3.2021

Ngày phản biên khoa học: 23.4.2021

Ngày duyệt bài: 4.5.2021

\section{Nguyễn Tiến Quang*}

without ADH.

Key words: Breast Papillary lesion, Clinicopathological feature, Immunohistochemistry.

\section{I. ĐĂT VẤN ĐỀ}

Tổn thương nhú chỉ chiếm $2 \%$ các tổn thương của tuyến vú nhưng tổn thương này lại có nhiều đặc điểm có thể gây nhẫm lẫn giữa lành tính, không điển hình và ác tính trong cả chẩn đoán, phân loại và điêuu trị [1]. Năm 2012, WHO đã phân loại các tổn thương nhú thành các nhóm: u nhú nội ống (UNNO) với các dạng UNNO kèm quá sản ống không điển hình $(A D H)$, UNNO kèm ung thư biểu mô ống tại chỗ (DCIS), UNNO kèm tân sản tiểu thùy; UTBM nhú nội ống; UTBM nhú trong vỏ loại xâm nhập và không xâm nhập; UTBM nhú đặc tại chố hoặc xâm nhập [2]. Trong tổn thương nhú, việc xác định tổn thương lành tính hay ác tính dựa vào sự có mặt của tế bào cơ biểu mô [3]. Tổn thương nhú rất đa dạng, các hình thái tổn thương đi từ lành tính, không điển hình tới ác tính và việc phân loại những tổn thương này vẫn là một thách thức trong chẩn đoán. Ở Việt Nam rất ít nghiên cứu về vấn đề này. Nhằm mục đích giải quyết những khó khăn nêu trên chúng tôi thực hiên đề tài này với mục tiêu: Nhận xét một số đặc điểm lâm sàng, mô bệnh học và hóa mô miễn dịch của các tổn thương nhú ở tuyên vú.

\section{II. Đốl TƯƠNG VÀ PHƯƠNG PHÁP NGHIÊN CỨU}

Đối tướng nghiên cứu: gồm mẫu bênh phẩm kèm theo hồ sơ bệnh án 79 bệnh nhân có tổn thương nhú của vú được sinh thiết hoặc phẫu thuật cắt u hoặc phẫu thuật cắt vú tại Bệnh viện $K$, từ tháng 5/2016 đến tháng 5/2018.

Tiêu chuẩn chọn bệnh nhân

- Có ghi nhận đầy đủ các dữ liệu: Họ tên, tuổi, ngày vào viện, vị trí khối u, chẩn đoán lâm sàng.

- Được phẫu thuật cắt khối u hoặc cắt bỏ tuyến vú.

- Khối u nguyên phát và chưa được điều trị hóa chất trước mổ cắt u.

- Có chẩn đoán MBH là tổn thương nhú của vú theo phân loại của WHO.

- Có khối nến đủ tiêu chuẩn để nhuộm HMMD.

Tiêu chuẩn loại trừ: Bệnh nhân không thỏa mãn các tiêu chuẩn trên

- BN có kèm các UT khác. 
- UT từ nơi khác di căn tới vú

- Tổn thương vú ở nam giới.

\section{Phương pháp nghiên cứu}

Thiết kế nghiên cứu: Nghiên cứu mô tả cắt ngang, hồi cứu kết hợp với tiến cứu.

Các bước tiến hành nghiên cứu

Ghi nhận các thông tín: Tên, tuổi, vị trí u, kích thước ù, chẩn đoán lâm sàng.

Nghiên cứu MBH: Phân loại mô học theo WHO 2012.

Nghiên cứu HMMD: Các mẫu mô được nhuộm HMMD bằng máy Ventana với các dấu ấn: Ki67. Đánh giá kết quả HMMD theo St Gallen năm 2013, chỉ số K67 được chia thành 2 mức độ: thấp (<20\%) và cao ( $\geq 20 \%)$.

Các biến số nghiên cứu: tuổi trung bình, nhóm tuổi; vú phải, vú trái, típ $M B H$, các biến đổi lành tính về biểu mô kèm theo (ADH, DCIS); sự bộc lộ của Ki-67.

Địa điểm nghiên cứu: Nghiên cứu này được thực hiện tại Bệnh viện K.

Xử lý số liệu: Xử lý số liệu trên phân mềm SPSS 20.0.

\section{KẾT QUẢ NGHIÊN CỨU}

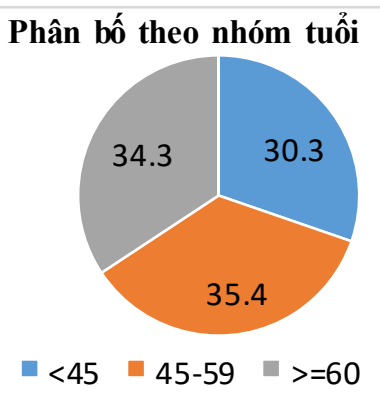

\section{Biểu đồ 1: Phân bố nhóm tuôi của tổn thương nhú của vú}

Nhânn xét: Tuổi mắc các tổn thương nhú của

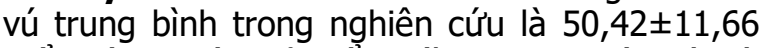
tuổi. Bệnh nhân trẻ tuổi nhất trong nghiên cứu là 30 tuổi và lớn tuổi nhất trong nghiên cứu là 81 tuổi. Nhóm tuổi gặp tổn thương nhú nhiều nhất là 45-59 tuổi chiếm tỉ lệ cao nhất 35,4\%. Nhóm tuổi nhỏ hơn 45 ít gặp tổn thương nhú của vú hơn (30,3\%).

Bảng 1. Tuôi trung bình của các nhóm tổn thương nhú của vú

\begin{tabular}{|c|c|c|}
\hline & $\begin{array}{c}\text { Tuối trung } \\
\text { bình }\end{array}$ & p \\
\hline $\begin{array}{c}\text { Nhóm tổn thương nhú } \\
\text { lành tính }\end{array}$ & $48,87 \pm 10,43$ & \multirow{2}{*}{0,036} \\
\hline $\begin{array}{c}\text { Nhóm tổn thương nhú } \\
\text { không điển hình }\end{array}$ & $48,85 \pm 11,34$ & \\
\hline
\end{tabular}

\begin{tabular}{|l|l|l|}
\hline $\begin{array}{c}\text { Nhóm tổn thương nhú } \\
\text { ác tính }\end{array}$ & $57,64 \pm 14,22$ & \\
\hline \multicolumn{3}{|c|}{ Nhận xét: Tuối trung bình của nhóm tổn }
\end{tabular} thương nhú ác tính cao nhất 57,64 tuổi. Sự khác biệt về tuổi trung bình của các nhóm là có ý nghĩa với $p=0,036<0,05$.

Bảng 2: Tỉ lệ phân bố theo vị trí của tổn thương nhú cúa vú

\begin{tabular}{|c|c|c|}
\hline Vị trí & Số trường hợp & Tỉ lệ (\%) \\
\hline Trái & 41 & 51,9 \\
\hline Phải & 38 & 48,1 \\
\hline
\end{tabular}

Nhânn xét: Vị trí của tổn thương nhú gặp ở hai bên vú phải và vú trái lần lượt là $48,1 \%$ và $51,9 \%$ với $p=0,736$ (>0.05). Như vậy, tổn thương nhú của vú phân bố không có sự khác biệt ở hai bên với mức ý nghĩa là 95\%.

Bảng 3. Phân loại típ tổn thương nhú của vú

\begin{tabular}{|c|c|c|}
\hline $\begin{array}{c}\text { Típ tổn thương nhú của } \\
\text { vú }\end{array}$ & $\begin{array}{l}\text { Số trường } \\
\text { hợp }\end{array}$ & $\begin{array}{l}\text { Tí lệ } \\
(\%)\end{array}$ \\
\hline \begin{tabular}{|c|} 
Lành tính \\
UNNO \\
\end{tabular} & $\begin{array}{l}52 \\
52 \\
\end{array}$ & $\begin{array}{l}65,8 \\
65,8\end{array}$ \\
\hline $\begin{array}{l}\text { Không điến hình } \\
\text { 1. UNNO kèm ADH } \\
\text { 2. UNNO kèm DCIS }\end{array}$ & $\begin{array}{c}13 \\
11 \\
2\end{array}$ & $\begin{array}{c}16,4 \\
13,9 \\
2,5\end{array}$ \\
\hline $\begin{array}{c}\text { Ác tính } \\
\text { 1. UTBM nhú nội ống } \\
\text { 2. UTBM nhú trong vỏ } \\
\text { 3. UTBM nhú trong vỏ xâm } \\
\text { nhập } \\
\text { 4. UTBM nhú đặc xâm nhập }\end{array}$ & $\begin{array}{c}14 \\
7 \\
3 \\
3 \\
1\end{array}$ & $\begin{array}{c}17,8 \\
8,9 \\
3,8 \\
3,8 \\
1,3\end{array}$ \\
\hline Tống & 79 & 100 \\
\hline
\end{tabular}

Nhận xét: UNNO là típ MBH có tỉ lệ cao nhất với 52 trường hợp chiếm $65,8 \%$, tiếp theo là UNNO kèm ADH với 11 trường hợp chiếm 13,9\%. UTBM nhú đặc xâm nhập chiếm tỉ lệ thấp nhất là 1,3 \% với 1 trường hợp được ghi nhận.

Bảng 4: Môi liên quán giữa ADH với các tổn thương nhú của vú

\begin{tabular}{|c|c|c|c|c|c|c|}
\hline \multicolumn{2}{|c|}{} & \multicolumn{2}{|c|}{ UNNO } & \multicolumn{2}{c|}{$\begin{array}{c}\text { UTBM } \\
\text { dạng nhú }\end{array}$} & \multirow{2}{*}{ p } \\
\cline { 3 - 6 } \multicolumn{2}{|c|}{} & $\mathbf{n}$ & $\%$ & $\mathbf{n}$ & $\mathbf{\%}$ & \\
\hline \multirow{2}{*}{ ADH } & Có & 11 & 16,9 & 8 & 57,1 & \multirow{2}{*}{0,01} \\
\cline { 2 - 6 } & Không & 54 & 83,1 & 6 & 42,9 & \\
\hline
\end{tabular}

OR=6,55 Khoảng tin cậy 95\%: 1,89-22,6

Nhận xét: Nhóm UTBM có cấu trúc nhú có kèm ADH nhiều hơn so với nhóm UNNO ghi nhận 8 trường hợp (chiếm 57,1\%). Nhóm UTBM có cấu trúc nhú kèm $A D H$ nhiêu hơn so với nhóm UNNO kèm $A D H$ có ý nghĩa thống kê $p=0,01<0,05$. Khảo sát hai yếu tố là UTBM có cấu trúc nhú và $A D H$ ta có tỉ suất chênh $\mathrm{OR}=6,55$, có ý nghĩa thống kê do khoảng tin cậy 95\% của OR nhận giá trị từ 1,89 đến 22,6 không 
chứa giá trị 1. Như vậy, khả năng phát triển thành UTBM có cấu trúc nhú của nhóm UNNO có kèm $A D H$ cao gấp 6,5 lần so với nhóm UNNO không kèm $A D H$.

Bảng 5: Môi liên quan giữa DCIS với các tổn thương nhú của vú

\begin{tabular}{|c|c|c|c|c|c|c|}
\hline \multicolumn{2}{|c|}{} & \multicolumn{2}{|c|}{ UNNO } & \multicolumn{2}{c|}{$\begin{array}{c}\text { UTBM } \\
\text { dạng nhú }\end{array}$} & \multirow{2}{*}{ p } \\
\cline { 3 - 6 } \multicolumn{2}{|c|}{} & $\mathbf{n}$ & $\mathbf{\%}$ & $\mathbf{n}$ & $\%$ & \\
\hline \multirow{2}{*}{ DCIS } & có & 1 & 14,3 & 6 & 83,7 & \multirow{2}{*}{0,00} \\
\cline { 2 - 6 } & Không & 61 & 92,4 & 5 & 7,6 & \\
\hline
\end{tabular}

$\mathrm{OR}=73,1$ Khoảng tin cây 95\%: 7,3-733,8

Nhân xét: Nhóm UNNO có 1 trường hợp duy nhất có phối hợp với DCIS, nhóm UTBM có cấu trúc nhú ghi nhận nhiều hơn với 6 trường hợp có kèm DCIS. Tỉ lệ phối hợp với DCIS của nhóm UNNO với nhóm UTBM có cấu trúc nhú là khác nhau có ý nghĩa thống kê với $p=0.00<0,05$. Khảo sát hai yếu tố là UTBM có cấu trúc nhú và DCIS, chúng tôi ghi nhận tỉ suất chênh $\mathrm{OR}=73,1$, có ý nghĩa thống kê do khoảng tin cậy $95 \%$ của OR nhận giá trị từ 7,3 đến 733,8không chứa giá trị 1. Như vậy, khả năng phát triển thành UTBM có cấu trúc nhú của nhóm có kèm DCIS cao gấp 73lần so với nhóm không kèm tổn thương DCIS.

Bảng 6: Mức độ tăng sinh Ki67 trong các tổn thương nhú của vú

\begin{tabular}{|c|c|c|c|c|c|}
\hline & \multicolumn{4}{|c|}{ Ki67 } & \\
\hline & \multicolumn{2}{|c|}{ Cao } & \multicolumn{2}{|c|}{ Thấp } & \\
\hline & $\mathbf{n}$ & $\%$ & $\mathbf{n}$ & $\%$ & \\
\hline UNNO & 0 & 0 & 52 & 100 & \\
\hline $\begin{array}{l}\text { Tốn thương nhú } \\
\text { không điển hình }\end{array}$ & 1 & 7,7 & 12 & 92,3 & $\begin{array}{c}P= \\
0,000\end{array}$ \\
\hline $\begin{array}{l}\text { Tốn thương nhú } \\
\text { ác tính }\end{array}$ & 5 & 35,7 & 9 & 64,3 & \\
\hline $\begin{array}{l}\text { UTBM nhú nội } \\
\text { ống }\end{array}$ & 1 & 14,3 & 6 & 85,7 & \\
\hline $\begin{array}{l}\text { UTBM nhú trong } \\
\text { vỏ }\end{array}$ & 4 & 66,6 & 2 & 33,3 & $\begin{array}{c}P= \\
0,061\end{array}$ \\
\hline UTBM nhú đặc & 0 & 0 & 1 & 10 & \\
\hline
\end{tabular}

Nhân xét: $100 \%$ típ UNNO có chỉ số Ki-67 thấp. Nhóm tổn thương nhú không điển hình có 1 trường hợp ghi nhận có chỉ số Ki-67 cao. Trong nhóm tổn thương nhú ác tính có 5 trường hợp có chỉ số Ki-67 cao chủ yếu gặp ở típ UTBM nhú trong vỏ. Trung bình của chỉ số Ki-67 trong nhóm tổn thương nhú ác tính của là 23,08 $\pm 20,87$ (dao động từ 5-80\%). So sánh mức độ tăng sinh Ki-67 giữa các nhóm tổn thương nhú lành tính, không điển hình là khác biệt có ý nghĩa với $\mathrm{p}=0,00<0,05$. Tuy nhiên, khi so sánh mức độ tăng sinh giữa các típ $\mathrm{MBH}$ trong tổn thương nhú ác tính thì không có sự khác biệt $p=0,061>0,05$.

\section{BÀN LUÂN}

Nghiên cứu 79 bênh nhân có tổn thương nhú ở vú của chúng tôi cho thây tuổi mắc trung bình của bệnh nhân có tổn thương nhú của vú là

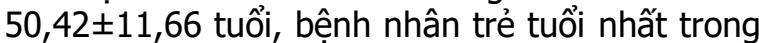
nghiên cứu là 30 tuổi và lớn nhất trong nghiên cứu là 81 tuổi. Tổn thương nhú của vú có nhóm tuổi phổ biến nhất là 45-59 tuổi (chiếm 35,4\%). Tuổi mắc bênh trong nghiên cứu của chúng tôi có sự khác biệt so với một số nghiên cứu khác như tác giả Tokiniwa và cộng sự (2011) ghi nhận tuổi trung bình của bệnh nhân có tổn thương nhú là 48,8 tuổi, trẻ hớn so với nghiên cứu của chúng tôi với tuối trẻ nhất là 22 và lớn nhất là 88 tuổi [4]. Nghiên cứu của chúng tôi cho thây tuổi mắc trung bình các tổn thương nhú không phải ác tính là 48,7 tuổi gần tương đương với nghiên cứu của Fu và cộng sự là 47 tuổi. Tuy nhiên, tuổi mắc trung bình của bệnh nhân có các tổn thương nhú ác tính trong nghiên cứu của chúng tôi là 57,64 tuổi, cao hơn so với nghiên cứu của Fu và cộng sự là 48,5 tuổi [6]. Điều này có thể là do ở Viêtt Nam việc phát hiện ung thư vẫn còn muộn dẫn đến phát hiện thường ở bệnh nhân lớn tuổi hơn, nhưng lại ở giai đoạn muộn hơn.

Về vị trí tổn thương, nghiên cứu của chúng tôi cho thây vị trí gặp tốn thương nhú ở vú phải là 54\% khác biệt không có ý nghĩa thống kê với vị trí gặp tổn thươngở vú trái là $61 \%(p=0,514$ $>0,05$ ). Như vậy khả năng gặp tổn thương nhú của vú là như nhau ở 2 bên trái và phải.

Típ mô bệnh học của các tổn thương nhú của vú: trong nghiên cứu của chúng tôi ghi nhận 7 típ mô bệnh học tổn thương nhú. Trong đó, tổn thương nhú gặp nhiều nhất có 52 trường hợp chiếm tỉ lệ $65,8 \%$ là UNNO lành tính.Các típ mô bệnh học ác tính ghi nhận 14 trường hợp chiếm $34,4 \%$, trong đó ung thư biểu mô nhú nội ống gặp nhiều nhất với 7 trường hợp. UNNO kèm ADH cũng ghi nhận được 11 trường hợp. Các típ ít gặp hơn là UNNO kèm DCIS (2 trường hợp chiếm $2,5 \%)$ và UTBM nhú đặc xâm nhập (1 trường hợp). Một số nghiên cứu trong nước và trên thế giới khác có ghi nhân tỉ lê phân típ mô bệnh học tương đương với nghiên cứu của chúng tổi. Pathmanathan và cộng sự (2010) cho thấy UNNO chiếm $61 \%$, nhóm các tổn thương không điển hình có $26 \%$ và nhóm các tổn thương ác tính chiếm 18\% [7]. Tạ Thị Minh Phượng và cộng sự (2015) thây rằng các tổn thướng nhú thuộc nhóm lành tính chiếm $50 \%$, nhóm các tổn thương không điển hình chiếm $22 \%$ và nhóm các tổn thương ác tính chiếm 28 [8]. Tỉ lệ gặp của các típ mô bệnh học rất thay đổi 
trong các nghiên cứu khác nhau. Bên cạnh đó, cõ mẫu của các nghiên cứu thường nhỏ nền tần suất các típ mô bệnh học hiếm gặp rất biến thiên.

Mối liên quan giữa ADH/DCIS với tổn thương nhú của vú: Trong 79 ca nghiên cứu, 17 trường hợp tổn thương nhú có kèm $A D H$, trong đó nhóm UNNO ghi nhận 11 trường hợp (chiếm $16,9 \%$ ) thấp hơn có ý nghĩa thống kê so với nhóm UTBM có cấu trúc nhú ghi nhâan 8 trường hơp (chiếm $57,1 \%) \quad(p=0,01<0,05)$. Khảo sát mối liên quan của $A D H$ với tổn thương nhú của vú tính toán được tỉ suất chênh $O R=6,55$, có ý nghĩa thống kê do khoảng tin cây $95 \%$ của OR nhận giá trị từ 1,89 đến 22,6 không chứa giá trị 1. Do đó, khả năng phát triển thành UTBM có cấu trúc nhú của nhóm tổn thương lành tính có kèm $A D H$ cao gấp 6,6 lần so với nhóm tổn thương lành tính không kèm tổn thương $A D H$.

So sánh với các nghiên cứu trên thễ giới, nghiên cứu của chúng tôi có kể quả tương tự với nghiên cứu của Page và công sư (1996), ông ây cũng thu được kết quả là yếu tố nguy cơ UTBM xâm nhập ở nữ có UNNO kèm $\mathrm{ADH}$ cao gấp $>4$ lần so với nhóm UNNO không kèm $A D H$ ở trong u nhú hoặc ở xung quanh u nhú [9]. Nghiên cứu của Lewis và cộng sự (2006) về phân tích nguy cơ ung thư vú ở những phụ nữ có UNNO đơn, đa ổ và kèm $A D H$ hoặc tân sản tiểu thùy có kết luận rằng: Nguy cơ ung thư vú ở những bệnh nhân có UNNO đơn độc kèm ADH tăng gấp 5,11 lần so với nhóm khồng kèm tổn thương không điển hình. Nghiên cứu của Dupont (1985) cũng ghi nhận nguy cơ ung thư vú ở bênh nhân có quá sản không điển hình cao gấp 5.3 lần so vớinhóm không có quá sản không điển hỉnh. Tổn thương quá sản không điển hình thì ngoài $A D H$ thì còn DCIS cũng rất cần thiết được đánh giá. Nghiên cứu của chúng tôi ghi nhận 7 trường hợp tổn thương nhú có kèm DCIS, trong đó tỉ lệ phối hợp của nhóm UNNO kèm DCIS thấp hơn có ý nghĩa so với nhóm UTBM có cấu trúc nhú kèm DCIS $(p=0,00<0,05)$. Đồng thời khảo sát hai yếu tố là UTBM có cấu trúc nhú với yếu tố DCIS có tỉ suất chênh $\mathrm{OR}=73,1$ có ý nghĩa thống kê do khoảng tin cậy $95 \%$ từ 7,3-733,8 không chứa giá trị 1, như vậy nguy cơ tiến triển thành UTBM cao gấp rất nhiều lần (73 lần) ở nhóm UNNO kèm DCIS so với nhóm UNNO không kèm DCIS. Nghiên cứu của chúng tôi và các nghiên cứu trên thế giới đều đưa ra chung một kết luận rằng: UNNO có kèm $A D H / D C I S$ làm tăng nguy cơ tiến triển thành UTBM.

Tỉ lệ bộc lộ của chỉ số Ki-67 trong tổn thương nhú của vú: Trong nghiên cứu của chúng tôi, ghi nhận $100 \%$ típ UNNO có chỉ số Ki-67 thấp điều này phù hợp với một tổn thương lành tính thì chỉ số tăng sinh cũng thấp. Nhóm tổn thương nhú không điển hình có 1 trường hợp ghi nhận có chỉ số Ki-67 cao - trường hợp này được chẩn đoán là UNNO kèm DCIS. Trường hợp này ta thây chỉ sô Ki- 67 ngoài vai trò tiên lượng còn là yếu tố giúp chẩn đoán phân biệt. So sánh mức độ tăng sinh Ki-67 giữa các nhóm tổn thương nhú lành tính, không điển hình và ác tính khác biệt có ý nghĩa với $\mathrm{p}=0.00<0.05$. Tuy nhiên, khi so sánh mức độ tăng sinh giữa các típ MBH trong tổn thương nhú ác tính thì không có sự khác biêt $p=0.11>0.05$. Kết quả này cũng phù hợp với nghiên cứu của Molino (1997), mức độ của chỉ số tăng sinh Ki-67 phụ thuộc với tuổi, kích thước khối u, tình trạng bộc lộ của $u$ với $E R, P R$ còn không phụ thuộc vào típ MBH.

\section{KẾT LUÂ̂N}

- Trong 7 típ MBH: UNNO là típ mô bênh học có tỉ lệ cao nhất $(65,8 \%)$, UNNO kèm DCIS $(2,5 \%)$ và UTBM nhú đặc xâm nhập $(1,3 \%)$ có tỉ lệ thấp nhất.

- Tổn thương $A D H$ và DCIS gă̆p nhiều trong nhóm UTBM có cấu trúc nhú hơn so với UNNO và khả năng phát triển thành UTBM có cấu trúc nhú ở nhóm có $A D H$ cao gấp 6,5 lần so với nhóm không có $A D H$. Khả năng phát triển thành UTBM có cấu trúc nhú ở nhóm có DCIS cao gấp 73 lần so với nhóm không có DCIS.

- Típ UNNO có chỉ số Ki-67 thấp (100\%). Nhóm tổn thương nhú ác tính có chỉ số Ki67 trung bình là $21.85 \%$.

\section{TÀI LIẸU THAM KHẢO}

1. Gendler L.S., Feldman S.M., Balassanian R. và cộng sự. (2004). Association of breast cancer with papillary lesions identified at percutaneous image-guided breast biopsy. Am J Surg, 188(4), 365-370.

2. S.R L., Elis I.O, S.J S. và cộng sự. (2012), WHO Classification of Tumors of the Breast, IARC, Lyon, France.

3. Kraus F.T. và Neubecker R.D. (1962). The differential diagnosis of papillary tumors of the breast. Cancer, 15(3), 444-455.

4. Tokiniwa H., Horiguchi J., Takata D. và cộng sư. (2011). Papillary lesions of the breast diagnosed using core needle biopsies. Exp Ther Med, 2(6), 1069-1072.

5. Bhargava, R, N.N E., và Dabbs D.J (2010). Immunohistology of the Breast. Diagnostic Immunohistochemistry: Theranostic and genomic application. Sauders, USA, 763-819.

6. Fu C.-Y., Chen T.-W., Hong Z.-J. và công sứ. (2012). Papillary breast lesions diagnosed by core biopsy require complete excision. Eur J Surg Oncol J Eur Soc Surg Oncol Br Assoc Surg Oncol, 
38(11), 1029-1035.

7. Pathmanathan N., Albertini A.-F., Provan P.J. và cộng sự. (2010). Diagnostic evaluation of papillary lesions of the breast on core biopsy. Mod Pathol Off J U S Can Acad Pathol Inc, 23(7), 1021-1028.

8. Ta Thị Minh Phương, Âu Nguyệt Diệu, và Hà
H.T.N. (2015). Đăc điểm giải phẫu bệnh, hóa mô miễn dich trong tổn thương dang nhú tuyến vú. Hoc TP Hồ Chí Minh, 19.

9. Page D.L., Salhany K.E., Jensen R.A. và cộng sư. (1996). Subsequent breast carcinoma risk after biopsy with atypia in a breast papilloma. Cancer, 78(2), 258-266.

\section{VIÊM MÀNG BỒ ĐÀO TRƯớC CẤP TÍNH DO VIRUS TRÊN NGƯỜI BÊ̂NH KHÔNG MẮC SUY GIẢM MIỄN DICCH}

\section{TÓM TẮT}

Muc tiêu: mô tả bênh cảnh lâm sàng và đối chiếu với kết quả xét nghiệm PCR thủy dịch của bệnh nhân không bị suy giảm miễn dịch mắc viêm màng bồ đào trước cấp tính Đối tượng và phương pháp nghiên cứu: nghiên cưú mô tả cắt ngang trên 30 bênh nhân bi VMBĐ trước cấp tính 1 bên mắt, lấy dich tiển phòng làm xét nghiêm PCR. Kết quả: 2 mắt có tăng nhãn áp; $100 \%$ bi đau đỏmắt; tỷ lê Tyndall tiên phòng $2+$, $3+$, 4+ lân lượt là $60 \%, 30 \%, 10 \% ; 6 / 30$ ca có kết quả PCR dương tính với CMV tương ứng với tủa trắng, không có ca nào dương tính với virus khác. Kết luận: cân xét nghiêm thường quy PCR dich tiền phòng trên bệnh nhân VMBĐ 1 mắt cấp tính để tìm nguyên nhân, qua đó có thể xác định phương pháp điều trị nguyên nhân hiệu quả.

Tư khóa: viêm màng bồ đào trước cấp, CMV, PCR thủy dịch

\section{SUMMARY \\ VIRAL ACUTE ANTERIOR UVEITIS IN IMMUNOCOMPETENT PATIENTS}

Purpose: Descibe the clinical features of unilateral acute anterior uveitis in the immunocompetent patients and comparing PCR result of humous aqueus sample. Materials and Methods: coss-sectional study, 30 eyes (30 patients) diagnosed of unilateral acute anterior uveitis, were taken the humous aqueus sample in anterior chamber to PCR test. Results: in 30 eyes, 2 eyes $(6,7 \%)$ were hypertonic, $100 \%$ were circumlimbal redness; 6 eyes were CMV + in PCR test regarding white keratic precipitates and none was positive with other virus. Conclusions: PCR test of humous aqueus sample should be the routine exam for unilateral acute anterior uveitis in the immunocompetent patients.

Keyword: acute anterior uveitis, CMV, humous aqueous PCR

\section{I. ĐĂT VẤN ĐỀ}

${ }^{1}$ Bệnh viên Mắt Trung ương

'Sở Y tế Thái Binh

Chịu trách nhiệm chính: Vũ Tuấn Anh

Email: vta.oph@gmail.com

Ngày nhân bài: 9.3.2021

Ngày phản biên khoa hoc: 28.4.2021

Ngày duyệt bài: 7.5.2021

\section{Vũ Tuấn Anh ${ }^{1}$, Hà Trung Kiên ${ }^{2}$}

Viêm màng bồ đào (VMBĐ) trước là một bệnh lý hay gặp nhất viêm nhiễm tổ chức nội nhãn, thường hay tái phát và có nhiều biến chứng, di chứng nặng nề, để lại hậu quả nghiêm trong làm ảnh hưởng đến chức nằng thị giác và cấu trúc nhãn cầu của người bệnh ${ }^{1}$. Việc điều trị VMBĐ trước hầu hết mới chỉ dừng lại ở điều trị triệu chứng và di chứng do không tìm được nguyên nhân gây bệnh rõ ràng.

Năm 2006, các tác giả Schryver, Rozenberg, Cason $x^{2}$ khi nghiên cứu tìm nguyên nhân trên 5 bênh nhân bị VMBĐ trước bằng cách lấy thủy dịch làm phản ứng chuỗi Polymerase (PCR) thì cả 5 trường hợp đều dương tính với Cytomegalovirus (CMV). Khi có bằng chứng về sự có mặt của CMV nội nhãn, 1 số tác giả đã điêu trị nguyên nhân bằng Ganciclovir tiêm nội nhãn cho kết quả khả quan, tỷ lệ khỏi bệnh cao, tỷ lệ tái phát thấp ${ }^{2,5,6,7}$.

Vì vậy, chúng tôi tiến hành nghiên cứu này mục tiêu: Mô tả bệnh cảnh lâm sàng và đối chiếu với kêt quả xét nghiệm PCR thưy dịch của bệnh nhân không bị suy giảm miễn dịch măc viêm màng bồ đào trước cấp tính

\section{II. ĐỐI TƯỢNG VÀ PHƯƠNG PHÁP NGHIÊN CỨU}

2.1. Đối tượng nghiên cứu. 30 bệnh nhân bị VMBĐ trước cấp tính 1 mắt trong 2 nẳm 20162017 đến khám và điều trị tại Bệnh viện Mắt Trung ương.

Tiêu chuẩn lựa chọn bệnh nhân: là những bệnh nhân đã được chẩn đoán xác định VMBĐ trước cấp một mắt, không bị suy giảm miễn dịch.

Tiêu chuẩn loại trừ:

- Những người bệnh già yếu trên 75 tuổi và trẻ dưới 15 tuổi do khó hợp tác trong nghiên cứu, những người có bệnh toàn thân không cho phép tham gia nghiên cứu như mắc bệnh tâm thần, bệnh tăng huyết áp, bênh tim mạch...

- Người bệnh đang có tổn thương viêm, loét giác mac kèm theo.

- Viêm MBĐ thứ phát sau chấn thương đụng 